\title{
Cloning of two pectate lyase genes from the marine Antarctic bacterium Pseudoalteromonas haloplanktis strain ANT/505 and characterization of the enzymes
}

\begin{abstract}
A marine Antarctic psychrotolerant bacterium (strain ANT/505), isolated from sea ice-covered surface water from the Southern Ocean, showed pectinolytic activity on citrus pectin agar. The sequencing of the $16 \mathrm{~S}$ rRNA of isolate ANT/505 indicates a taxonomic affiliation to Pseudoalteromonas haloplanktis. The supernatant of this strain showed three different pectinolytic activities after growth on citrus pectin. By activity screening of a genomic DNA library of isolate ANT/505 in Escherichia coli, two different pectinolytic clones could be isolated. Subcloning and sequencing revealed two open reading frames (ORF) of 1,671 and $1,968 \mathrm{nt}$, corresponding to proteins of 68 and $75 \mathrm{kDa}$, respectively. The deduced amino acid sequence of the two ORFs showed homology to pectate lyases from Erwinia chrysanthemi and Aspergillus nidulans. The pectate lyases contain signal peptides of 17 and 26 amino acids that were correctly processed after overexpression in E. coli BL21. Both enzymes were purified by anionic exchange chromatography. Maximal enzymatic activities for both pectate lyases were observed at $30^{\circ} \mathrm{C}$ and a $\mathrm{pH}$ range of 9 to 10 . The $K_{\mathrm{m}}$ values of both lyases for pectate and citrus pectin were $1 \mathrm{~g} \mathrm{l}^{-1}$ and $5 \mathrm{~g} \mathrm{l}^{-1}$, respectively. Calcium was required for activity on pectic substrates, whereas the addition of $1 \mathrm{mM}$ ethylenediaminetetraacetic acid (EDTA) resulted in complete inhibition of the enzymes. These two
\end{abstract}

Communicated by K. Horikoshi

L.V. Truong $\cdot$ H. Tuyen $\cdot$ L.T. Binh

Institute of Biotechnology, National Center of Natural Science and Technology, Tu Liem, Hanoi, Vietnam

E. Helmke

Alfred Wegener Institute for Polar and Marine Research,

Bremerhaven, Germany

T. Schweder $(\bowtie)$

Institute of Marine Biotechnology, W.-Rathenau Str. 49a, D-17489

Greifswald, Germany

Tel. +49-3834-864212; Fax +49-3834-864202

e-mail: Schweder@microbio1.biologie.uni-greifswald.de enzymes represent the first pectate lyases isolated and characterized from a cold-adapted marine bacterium.

Key words Pectate lyase $\cdot$ Pectin $\cdot$ Psychrophilic $\cdot$ Marine Pseudoalteromonas haloplanktis

\section{Introduction}

The marine phytoplankton of permanently cold environments produces a variety of structural polymers such as cellulose and xylan. Although relatively few data are available concerning the hydrolysis of such compounds under lowtemperature conditions, it is obvious that these structural polymers can be degraded by marine microorganisms. Cummings and Black (1999) reported screening for xylanand cellulose-degrading microorganisms from the $3^{\circ} \mathrm{C}$ cold marine sediment of shallow waters around Adelaide Island, British Antarctica. They isolated a xylanolytic gramnegative bacterium with an optimal growth rate at $15^{\circ} \mathrm{C}$.

Pectin, the important structural constituent of plant cell walls, is composed essentially of long chains of $(1,4)-\alpha-\mathrm{D}-$ polygalacturonate, which are partially methyl esterified. Although pectin is of secondary importance for the marine environment, it is supposed that this polymer is also degraded by marine microorganisms (Cummings and Black 1999). Microbial pectin degradation is accomplished by methylesterases, which remove the methyl groups from pectin, and the depolymerases, which degrade both pectin and pectate (Whitaker 1991). Bacteria produce mainly pectate lyases, which require an alkaline $\mathrm{pH}$ and $\mathrm{Ca}^{2+}$ for their optimal enzyme activity. Reports on pectinases from coldadapted microorganisms are so far restricted to psychrotolerant spoilage bacteria such as different strains of Pseudomonas fluorescens (Schlemmer et al. 1987). Recently, the production of pectate lyases by the psychrotolerant bacterium Chryseomonas luteola has been described (Laurent et al. 2000). This bacterium, which has been isolated from spoiled celeriac, is able to macerate 
plant tissue at low temperatures by means of at least three extracellular pectate lyases.

We report here the isolation of a pectinolytic marine bacterium from Antarctic sea ice. This psychrotolerant marine bacterium produces at least two pectate lyases. The genes of both enzymes were cloned and sequenced, and the pectate lyases were purified and characterized.

\section{Materials and methods}

Strains and cultivation conditions

The strain ANT/505 has been isolated from sea ice-covered surface water collected in the Antarctic Ocean at 58 58.07' $\mathrm{S}$ and $06^{\circ} 41.98^{\prime} \mathrm{E}$ using ZoBell medium at an incubation temperature of $2^{\circ} \mathrm{C}$ (Weyland et al. 1970). The pure culture was maintained on Marine Agar 2216 (Difco, Detroit, MI, USA) at $2^{\circ} \mathrm{C}$. The tests for utilization of organic compounds as sole carbon and nitrogen source were carried out in liquid basal medium seawater (BMS) (Helmke and Weyland 1984). The enzymatic activities of amylases, chitinases, ureases, and nitrate reductases were determined by the method of Weyland et al. (1970). Alginase activity was measured according to Ahrens (1968). All physiological tests were performed at an incubation temperature of $5^{\circ} \mathrm{C}$.

E. coli DH5 $\alpha$ was used for the preparation of the gene library. E. coli BL21(DE3) (pLysS) was used for the overproduction of the pectate lyases. E. coli cells were routinely cultivated under vigorous agitation at $37^{\circ} \mathrm{C}$ in LuriaBertani (LB) medium. The marine strain ANT/505 was cultivated for 2 days at $16^{\circ} \mathrm{C}$ on a modified ZoBell medium with $0.25 \%(\mathrm{w} / \mathrm{v})$ citrus pectin (Sigma, München, Germany). The ZoBell medium with the following composition was used: $750 \mathrm{ml} \mathrm{ASW}$ [artificial seawater with a salinity of $2.7 \%$ according to Burkholder (1963)] containing $24 \mathrm{~g} / \mathrm{l} \mathrm{NaCl} ; 5.3 \mathrm{~g} / \mathrm{l} \mathrm{MgCl} 6 \mathrm{H}_{2} \mathrm{O} ; 7 \mathrm{~g} / 1 \mathrm{MgSO}_{4} ; 0.7 \mathrm{~g} / \mathrm{l} \mathrm{KCl}$; $0.01 \mathrm{~g} / 1 \mathrm{FeSO}_{3} ; 5 \mathrm{~g} / \mathrm{l}$ peptone; $1 \mathrm{~g} / \mathrm{l}$ yeast extract; and $10 \mathrm{~g} / \mathrm{l}$ $\mathrm{FePO}_{4}$. Before autoclaving, the $\mathrm{pH}$ was adjusted to 7.6.

\section{Nucleic acid manipulation}

Chromosomal DNA from strain ANT/505 was prepared according to Sambrook et al. (1989). Plasmid DNA was purified by the alkaline lysis procedure (Sambrook et al. 1989). Chromosomal DNA was partially digested with Sau3AI; fragments of $4 \mathrm{~kb}$ were isolated from $0.8 \%(\mathrm{w} / \mathrm{v})$ agarose gel with the Agarose Gel DNA Extraction Kit from Roche Diagnostics (Penzburg, Germany). These fragments were ligated to BamHI-digested pUC18. The ligated plasmids were transformed in competent $E$. coli $\mathrm{DH} 5 \alpha$ cells (Hanahan 1983) and selected on LB agar plates containing $100 \mathrm{mg} / \mathrm{l}$ ampicillin. Clones with pectinase activity were determined on LB agar plates containing $0.25 \%$ (w/v) citrus pectin after overnight cultivation at $37^{\circ} \mathrm{C}$ and a subsequent incubation at room temperature (RT) for 2 days. The colo- nies of positive pectinase-producing clones were identified by staining the plates with $1 \%(\mathrm{w} / \mathrm{v})$ of hexadecyl trimethyl ammonium bromide solution (Sigma) for $3 \mathrm{~h}$.

The sequence of positive clones was determined by automated fluorescence sequencing with an ABI PRISM dye terminator cycle sequencing reaction mix (Perkin-Elmer, Rodgau-Jügesheim, Germany) in a 377 Perkin-Elmer DNA sequencer. The nucleotide sequences reported in this article have been submitted to the Genbank/EMBL Data Bank with the accession numbers AF278706 for pelA and AF278705 for pelB.

For the overproduction of the pectate lyases, the coding sequences of both genes were cloned into the $\mathrm{T} 7$ expression vector pRSET-A (Invitrogen, Groningen, Netherlands). Ligated plasmids were transformed into E. coli BL21 (DE3) pLysS. Construction of plasmid pRSETpelA was performed by cloning of a 1,764-bp BamHI/Eco RI PCR fragment (primers pelAf gataaggatccgatgcaagacagcgacgtg and pelAr gcttcgaattccgcacaaagagaaaggaat) covering the coding region including the potential signal sequence of pelA into pRSET-A. Plasmid pRSETpelB was constructed in a similar way by cloning of a 2,058-bp BamHI/Eco RI PCR fragment (primers pelBf ataaggatccgatgaaaaaaactaatatt and pelBr gcttcgaattccttaaagttctgagcgcg) covering the coding region including the potential signal sequence of pelB into pRSET-A.

E. coli BL21 cells carrying pRSETpelA or pRSETpelB were grown overnight on $5 \mathrm{ml}$ LB. Three milliliters of the culture medium was transferred to $150 \mathrm{ml} \mathrm{LB}$ medium in a $500-\mathrm{ml}$ shake flask. The culture was incubated at $37^{\circ} \mathrm{C}$ and $230 \mathrm{rpm}$ until an optical density (OD) $(600 \mathrm{~nm})$ of $0.4-0.5$. Subsequently, the induction was initiated by addition of $1 \mathrm{mM}$ isopropyl thiogalactoside (IPTG) (final concentration). After $5 \mathrm{~h}$ cultivation at $30^{\circ} \mathrm{C}$, the culture was centrifuged at $10,000 \mathrm{rpm}$ for $10 \mathrm{~min}$ at $4^{\circ} \mathrm{C}$. The supernatant and the pellet were collected and stored at $4^{\circ} \mathrm{C}$.

Purification of the pectate lyases

The cell pellet from isolate ANT/505 or from E. coli after overexpression was resuspended in $1 / 10$ volume of $50 \mathrm{mM}$ Tris buffer ( $\mathrm{pH} 7.5$ ), and lysozyme to a final concentration of $50 \mu \mathrm{g} / \mathrm{ml}$ was added. After incubation for $30 \mathrm{~min}$ at $37^{\circ} \mathrm{C}$, the debris of the cell wall and the protoplasts were centrifuged for $5 \mathrm{~min}$ at $10,000 \mathrm{rpm}$ and $4^{\circ} \mathrm{C}$. The periplasmatic protein fraction in the supernatant was concentrated to approximately $0.5 \mu \mathrm{g} / \mu \mathrm{l}$ by centrifugation $\left(5,000 \mathrm{rpm}, 4^{\circ} \mathrm{C}\right)$ with filter membranes (Ultrafree-30) from Millipore (Bedford, MA, USA).

The sample was applied to a DEAE Sepharose column in $10 \mathrm{mM}$ Tris buffer ( $\mathrm{pH} 8.5$ ) containing $0.6 \mathrm{mM} \mathrm{CaCl}$. After washing the column with the same buffer, the proteins were eluted by a gradient of $0-1 \mathrm{M} \mathrm{NaCl}$ in $200 \mathrm{mM}$ Tris buffer $(\mathrm{pH} 8.5)$ with $0.6 \mathrm{mM} \mathrm{CaCl}$. The eluted fractions showing activity on pectin acid were collected and concentrated with membrane filters as described earlier. The sample was applied to a Resource Q 6-ml column (Pharmacia Biotech, Freiburg, Germany) in $10 \mathrm{mM}$ Tris 
buffer ( $\mathrm{pH} 8.5$ ) containing $0.6 \mathrm{mM} \mathrm{CaCl}$. After washing with the same buffer, the proteins were eluted by a gradient of $0-1 \mathrm{M} \mathrm{NaCl}$ in $200 \mathrm{mM}$ Tris buffer ( $\mathrm{pH} 8.5)$ with $0.6 \mathrm{mM}$ $\mathrm{CaCl}_{2}$. The sample was applied to a gel filtration column (Superdex 75; Pharmacia Biotech) and eluted by $10 \mathrm{mM}$ Tris buffer (pH 8.5).

\section{Enzyme assays}

Citrus pectin and the potassium salt of polygalacturonic acid from oranges supplied by Sigma were used for the enzyme assays. The degree of esterification of the pectin was approximately $60 \%$. Pectate lyase activity was measured by the determination of reducing sugars (Bernfeld 1955); $50 \mu \mathrm{l}$ of enzyme solution was mixed with $450 \mu \mathrm{l}$ $50 \mathrm{mM}$ Tris- $\mathrm{HCl}$ buffer ( $\mathrm{pH} 9.5)$ containing $0.25 \%(\mathrm{w} / \mathrm{v})$ pectin acid, $20 \mathrm{mM} \mathrm{NaCl}$, and $0.1 \mathrm{mM} \mathrm{CaCl}_{2}$. The samples were incubated at $30^{\circ} \mathrm{C}$ for $60 \mathrm{~min}$. For determination of reducing sugars, $0.5 \mathrm{ml}$ of dinitrosalycilic acid solution was added. The samples were boiled for $10 \mathrm{~min}$ and cooled to RT. After centrifugation for $5 \mathrm{~min}$ at $10,000 \mathrm{rpm}$, the samples were measured spectrophotometrically at $530 \mathrm{~nm}$. Sample blanks were used to correct for nonenzymatic release of the reduced sugar. One unit of pectate lyase activity was defined as $1 \mathrm{nM}$ of reducing sugar liberated per minute. For the determination of unsaturated bonds according to Collmer et al. (1988), the reaction was stopped by addition of $0.5 \mathrm{ml}$ sodium citrate buffer $0.4 \mathrm{M}(\mathrm{pH} 4.0)$, centrifuged at $10,000 \mathrm{rpm}$ for $5 \mathrm{~min}$, and measured at $235 \mathrm{~nm}$ in the spectrophotometer.

Protein electrophoresis and $\mathrm{N}$-terminal protein sequencing

Denaturating protein gel electrophoresis was performed with a $10 \%(\mathrm{w} / \mathrm{v})$ polyacrylamide gel as described by Sambrook et al. (1989). For the native protein gel electrophoresis, a $10 \%(\mathrm{w} / \mathrm{v})$ polyacrylamide gel without sodium dodecyl sulfate (SDS) was used. After electrophoresis, the native gels were rinsed with Tris buffer $50 \mathrm{mM}$ (pH 9.5) containing $20 \mathrm{mM} \mathrm{NaCl}$ and $0.1 \mathrm{mM} \mathrm{CaCl}_{2}$ for $10 \mathrm{~min}$. The native gel was overlaid with a second gel containing $0.1 \%(\mathrm{w} / \mathrm{v})$ pectate in $100 \mathrm{mM}$ Tris buffer (pH 9.5) with $20 \mathrm{mM} \mathrm{NaCl}$ and $0.1 \mathrm{mM} \mathrm{CaCl}$ and incubated at $30^{\circ} \mathrm{C}$ for $1 \mathrm{~h}$. The overlay gel was stained with $0.1 \%$ ruthenium red (Sigma) for 10 min and washed in distilled water. The N-terminal protein sequencing was done as described by Völker et al. (1992).

\section{Results}

Screening of cold-adapted marine bacteria with pectinolytic activity

Bacteria from water and sediment samples from the Antarctic and Arctic ocean from sea ice, seawater, and sedi-
Table 1. Differential characteristics of the species Alteromonas haloplanktis $^{\mathrm{a}}$ and the isolate ANT/505

\begin{tabular}{|c|c|c|}
\hline Characteristics & Alteromonas haloplanktis ${ }^{\mathrm{a}}$ & $\begin{array}{l}\text { ANT/505 } \\
\text { strain }\end{array}$ \\
\hline Growth at $4^{\circ} \mathrm{C}$ & - & + \\
\hline $\begin{array}{l}\text { Reduction of nitrate to } \\
\text { nitrite }\end{array}$ & $\mathrm{d}$ & - \\
\hline \multicolumn{3}{|l|}{ Production of: } \\
\hline Amylase & d & + \\
\hline Alginase & - & + \\
\hline Chitinase & $\mathrm{d}$ & - \\
\hline Urease & $\mathrm{d}$ & - \\
\hline \multicolumn{3}{|l|}{ Utilization of: } \\
\hline D-Galactose & $\mathrm{d}$ & + \\
\hline d-Fructose & d & + \\
\hline Cellobiose & - & + \\
\hline Salicin & - & + \\
\hline Succinate & + & - \\
\hline Citrate & + & - \\
\hline D-Mannitol & $\mathrm{d}$ & + \\
\hline Glycerol & - & + \\
\hline L-Arabinose & $\mathrm{d}$ & - \\
\hline Trehalose & $\mathrm{d}$ & - \\
\hline Acetate & + & - \\
\hline Propionate & + & - \\
\hline L-Serine & + & - \\
\hline L-Leucine & $\mathrm{d}$ & - \\
\hline
\end{tabular}

Boldface type indicates traits useful for the preliminary identification of Pseudoalteromonas species

$\mathrm{d}$, differs among strains

aBergey's Manual of Systematic Bacteriology (1984)

ment were screened on ZoBell medium agar containing $0.25 \%(\mathrm{w} / \mathrm{v})$ citrus pectin, apple pectin, or polygalacturonic acid. Colonies showing a clear halo after addition of ruthenium red were selected. The biggest halo showed a strain isolated from Antarctic sea ice from surface water in the Southern Ocean (Weyland et al. 1970). This isolate was called strain ANT/505 (Table 1 ). This strain is a psychrotolerant marine bacterium that grows in a temperature range from $0^{\circ}$ to $29^{\circ} \mathrm{C}$. The optimal growth temperature was $23^{\circ} \mathrm{C}$. The $16 \mathrm{~S}$ rDNA sequencing of isolate ANT/505 showed a $100 \%$ homology to the Antarctic strain Pseudoalteromonas haloplanktis.

The highest level of pectinolytic activity of isolate ANT/ 505 on citrus pectin or pectate was determined in the late stationary phase (Fig. 1). The major part of the pectinolytic activity could be found in the supernatant. However, the pellet also showed pectinase activity during growth on pectate or citrus pectin, indicating an additional cell wall-associated or periplasmic pectinolytic activity. This cell wallassociated pectinase activity could be released by treatment of the cells with lysozyme (data not shown). The separation of the extracellular protein fraction of a stationary ANT/ 505 culture in a native polyacrylamide gel overlaid with $0.1 \%(\mathrm{w} / \mathrm{v})$ citrus pectin indicated that strain ANT/505 
Fig. 1. Growth curve of strain ANT/505 (dotted line) cultivated at $16^{\circ} \mathrm{C}$ in ZoBell medium containing citrus pectin and the corresponding extracellular [on citrus pectine (solid squares) and pectate (solid circles)] or cell wall-associated [on citrus pectine (open squares) and pectate (open circles)] pectinolytic activities

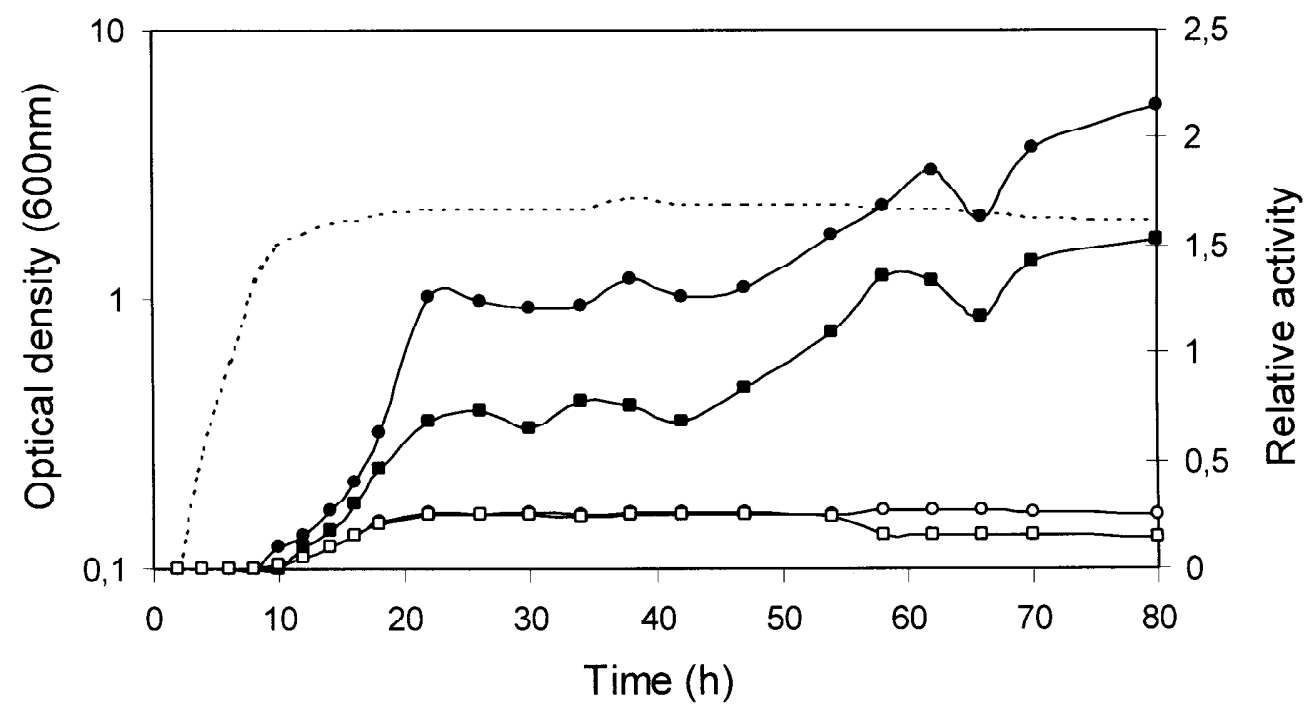

plates containing $0.1 \%(\mathrm{w} / \mathrm{v})$ citrus pectin showed five colonies with pectinolytic activity. The DNA inserts of the clones were 3-4 kb long. The DNA sequencing showed open reading frames (ORFs) of 1,671 and 1,968 nt, corresponding to proteins of 68 and $75 \mathrm{kDa}$, which were named PelA and PelB (Fig. 3). The N-terminal part of the deduced amino acid sequence of the two ORFs showed homology to pectate lyases from Erwinia chrysanthemi (Keen and Tamaki 1986; Tamaki et al. 1988) and Aspergillus nidulans (Ho et al. 1995). The highest homology of PelA was found to pelA of $A$. nidulans ( $48 \%$ identity). PelB showed the highest homology to pelA of E. chrysanthemi (34\% identity). According to the classification of pectate lyases (Shevchik et al. 1997), PelA and PelB belong to class I. The typical conserved regions of the class I pectate lyases could be also found in PelA and PelB (Fig. 3).

PelA and PelB contain a signal peptide of 17 and 26 amino acids, respectively, with the typical features of signal peptides of the Sec-dependent secretion pathway. Both pectate lyases reveal an unusually long C-terminal part, which comprises about 190 amino acids in the case of PelA and about 300 amino acids in the case of PelB (data not shown). The C-terminal amino acid sequence of PelB showed homologies to sequences of known xylanases. cellular protein extract of strain ANT/505 $(A)$ stained with Coomassie blue and $(B)$ the overlay gel with $0.1 \%$ pectin acid, stained with ruthenium red. The pectinolytic bands are indicated with arrows

secretes three different pectinases into the extracellular medium (Fig. 2).

Cloning and sequencing of two pectate lyase genes of P. haloplanktis strain ANT/505

The screening of approximately 15,000 clones of a genomic library of strain ANT/505 in E. coli DH5 $\alpha$ on LB-agar

Purification and characterization of the two pectate lyases

The coding sequences of pelA and pelB were cloned into the T7 expression vector pRSET-A. For overproduction of both pectate lyases in E. coli (DE3) BL21, the expression system was introduced by the addition of $1 \mathrm{mM}$ IPTG at $30^{\circ} \mathrm{C}$ followed by a further cultivation for approximately 5 $\mathrm{h}$ at $30^{\circ} \mathrm{C}$. After overproduction of PelA or PelB in E. coli, only PelB could be found in the extracellular medium, whereas PelA was mainly located in the periplasm (data not shown). PelA and PelB were partially purified from the 
Fig. 3. Alignment of the amino acid sequences of the pectate lyases PelA and PelB of strain ANT/505 with known pectate lyases of class I. The C-terminal amino acid sequence of PelA and PelB is not shown. Conserved regions are indicated by boxed areas. The grade of conservation of the appropriate amino acids is indicated by an asterisk (highly conserved), a colon (medium conserved), or a dot (low grade of conservation)
F.chrys. pelB E.chrys. pelc E.chrys. peld E.chrys. pele E.chrys. pelA A.nidul, pelA ANT $/ 505$ pelB ANT $/ 505$ pelA

Prim.cons.

E.chrys, peit E.chrys. pelc E.chrys. peid E.chrys, peith E.chrys, peid A. nidul, pela ANT $/ 505$ pelB ANT $/ 505$ pelA

Prim.cons.

E.chrys. pelB E.chrys. pelc E.chrys. peld E.chrys. pele E.chrys, pela A. nidiul pela ANT $/ 505$ pelB ANT/505 pold

prim.cons.

E.chrys. pele E.chrys. peIC E.chrys. peld E.chrys. pele E.chrys. pelA A.nidul. pela ANT $/ 505$ pelB ANT/505 pelA

Prim.cons.

E.chrys. pelB E.chrys. pelc E.chrys. peld E.chrys. peIE E.chirys. pela A.nidul. pela ANT/505 pelB ANT/505 pela

Prim.cons.

E.chrys. $p$ ele E.chrys. pelc E. chrys. pe1D E.chrys, pele E.chrys. pela A.nidul pela ANT $/ 505$ pelB ANT/505 pelA

Prim.cons

E.chrys. pelB E.chrys. pelC E.chrys. peld E.chrys. pele E.chrys. pelA A.nidul. pela ANT/505 pelB ANT $/ 505$ pelA

Prim.cons

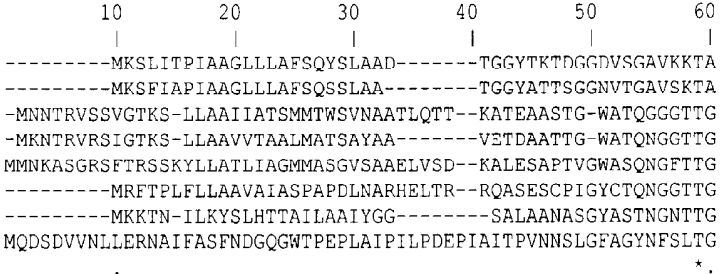

MMNNTRVRSMK32S53LAAGL23A2MASSLAAA4L 4T4 PI22T2AATTGGWATONGGTTG

$\begin{array}{llllll}70 & 80 & 90 & 100 & 110 & 120\end{array}$

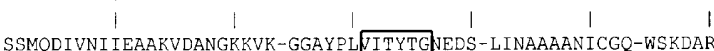
ASMODI IDI I DAAKVDSRGKRVR-GGAYPL IITYTG IEDS-LINAAAANICGQ-WSKDAR GAKAASAKI YAVKNISEFKAAINGTDTDPK IOVTGAIDI-SGGKAYTSFDDQ-KARSOI GAKAA--KAVEVKNISDFKKALNGTDSSAKE IKVTGPIDI-SGGKAYTSFDDQ-KARSQI GAAATSDNIYIVTNISEFTSALS-AGAEAK IQI KG PIDI-SGGTPYTDFADQ-KARSQI GAAGD---TVTVTNLADLTEAAE--SDGPLEIIVSGEIS--.-----G-------S-AKI GAGGDVVYATTGTOIHOALCNRA-SSDTPI IQVEGPINHGNTSKVSGDSCNTGPDLIEL GEGGTVVTVDNGTALKSALAQAK-SLGVPEIYYVG ITDANSG---GDNSS-----IEI GA42D3V2I 32VTNIS3E4KALKG3GAYP2IIQVTG2IDI2SGGKAY2DFCDQGK2RSQI

$\begin{array}{rrrrrr}130 & 140 & 150 & 160 & 170 & 180 \\ 1 & 1 & \mid & 1 & \mid\end{array}$ GVEIKDFTKGLTI I GANGSSANEGIWINN---S SUIVVRNMRI GVEIKDFTKGITI IGANGSSANAGLWI IN---SSDVVVRNMRI I--..----YLPGG--A SVPSNTTIIG---IGSNGKFTNGSLVIKG---VENVILRNLYIETPVDVAPHYEEGDGWN SIPSNTTIIG---VGSNGKFTNASLVIKG---VKNVILRNLYIETPVDVAPHYESGDGWN NIPANTTVIG---LGTDAKFINGSLITDGTDGT NNVI I RNVYI ITPIDVEPHYEKGDGWN RVASDKT T FG----F.SGSS I TGT GFY TRR---V VNV IMRNT,K TS--------KVDAD--N KEISNVS I IG---VGSGALFDQLGIHIRS---S 5 NI I I QNVHVRN---..--VKKSGSPIS

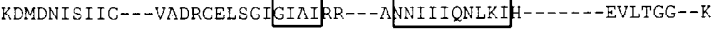

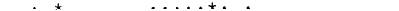

3VPSNTTI IG2TI2GSNG2FTNGGL2I RGTDG2SNVIIRNLYI2TPVDVAPHY22GDGWN

$190 \quad 200 \quad 210 \quad 220 \quad 230 \quad 240$ QDGDMFRIDN--SPN 7WLDHNEIFAANHECDG--TRDGD--TI ESAIDIKKGATYVTIS QDGDMFRIDN--SPNWWLDHNEI FAANHECDG--TKDGD- TT EESAFDI KKGATYVTIS

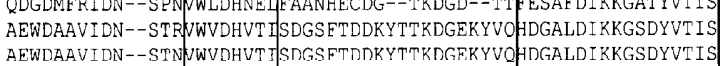
AEWDAMNITNG-AHHWWIDHVT I SDGNETDDMYT'TKDGETYVQHDGALDI KRGSDYVTIS --GDATGIDA--SSMVWVDHCDISGDLSGGKD--.-.-----DEDGLVDI SHGAEWITVS NGGDAI GMESN-VRN JWVDHVT I EASGGESSG-........ PDALFDMRNNTKYVTLS DGISIEGDENKPTANU WI DHNEIYSSLNVDQD--------P YDGLIDSKSGAENITIS AEGDA3GIDN3PS2NVWVDHVTLS2GNE2DDGYTTKDGEKYVQHDGALDI KKGADYVII IS \begin{tabular}{|l}
250 \\
YNYIHGVKKVGLSGFSSSD PAERN---
\end{tabular}
310
320
330
340
350
360 TSSCLNVROACRNLI ITSSGLNVRQNGKALI ENNWFENAVNPVTSRYDGSNFG-- TWVLKNNNITKPADFATYNDVKNSVYPYLYSFGLGTS----GSILSESNSFTLSNLKSIDGRNPECS IVRQFNSKVESD DVKHSVYPYLYSFGLGTS----GSILSESNSETLSNLKSIDGKNPECSIVKQFNSKVFSD DAKDPVYRYQYSFGIGTS----GSVLSEGNSFTIANLS----ASKACKVVKKFNGS IFSL - TDTGVNCRMDAQVLIOS --.--SAFHNCPDRATFFADS----DYTGYAVVDDVDLGGSSIQSSGMNPRIGGKIRAEN----NYFQDSKDPLGTFYTN-----DMYWQVSG----NIWDN ITSSAINSRMGAELH IEN----NYFEHTKNPVVSFYSK----VIGYWNTSGNYLGEGVTW

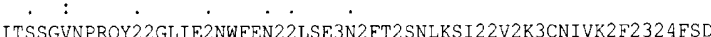
380 390 400 410 420 ITWTPDTKEYRNADTWTSTGTYPTVPYSYSPVSAOCVKDKLANYAGVGKNLATLASSACK ITWTADTKAYVNADSWT STGTYPAVTYSYS PVSAQCVKDKLASYAGVGKNLAELTSAACK NGSLVNGSSTTKLDTCGLTAYKPTLPYKYS---AQTMTSSLASSINSNAGYGKL------KGSLVNGSTTTKLDTCGLTAYKPTLPYKYS---AQTMTSSLATSINNNAGYGKL-----NGSVLNGS-AVDLSGCGESAYTSKIPYIYD-- -VQPMTTELAQSITDNAGSGKL------NSVPEGT---------LTPSSLPYAAIT----ALGSGOVASVI PGTAGQKL-----IDWSEDESKLHPAGPNPSSTTS ISI PYNYOIDNTOCVPA I I AATAGANKGLKESNGECGT GDVADGDVAAEVTATGMTPTSSYOAPYEYKLTPVMDVKAHVIAHAGIGKTDOSDLDI PDI

IGS322GSA3222DTCGSTAT3PTLPYY2YS2VSAOCV2S2LAASAGV2KGLGKL4S4ACK 


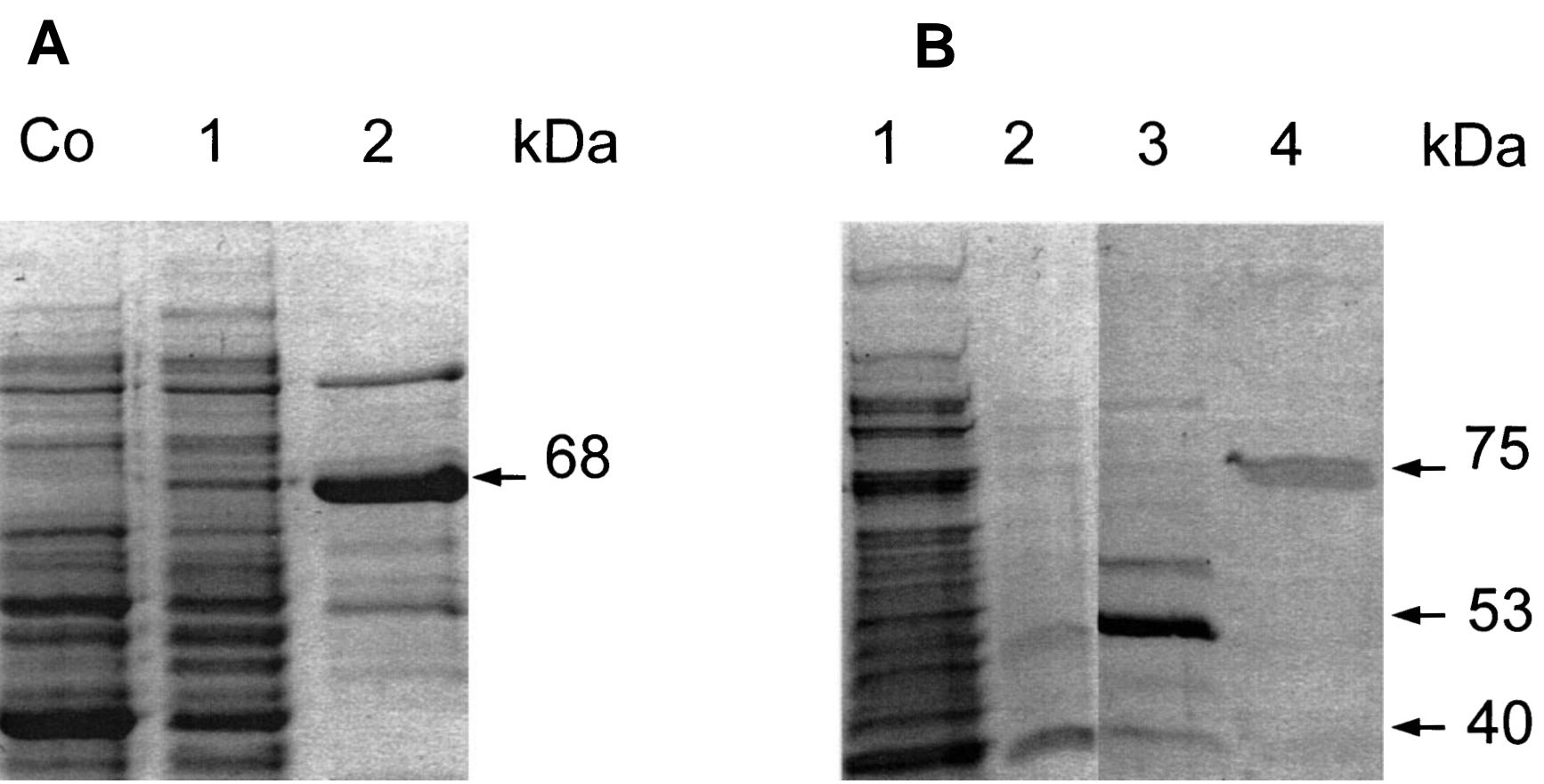

Fig. 4A, B. SDS-PAGE of the pectate lyases of strain ANT/505 after overproduction with the T7 expression system in $E$. coli BL21 and after purification. A PelA: Co, E. coli (DE3) BL21 control without overexpression; 1, periplasmatic protein fraction of E. coli BL21 cells after overproduction of PelA; 2, purified PelA protein fraction. B PelB: 1, extracellular plus periplasmatic protein fraction of E. coli BL21 cells after overproduction of PelB; 2, first purified PelB protein fraction; 3, second purified PelB protein fraction; 4, third purified PelB protein fraction

A

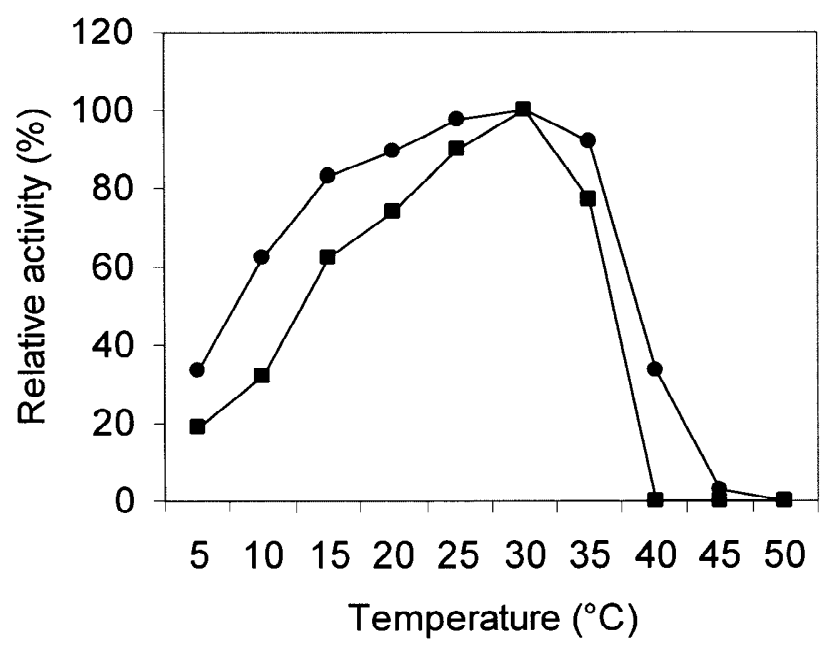

B

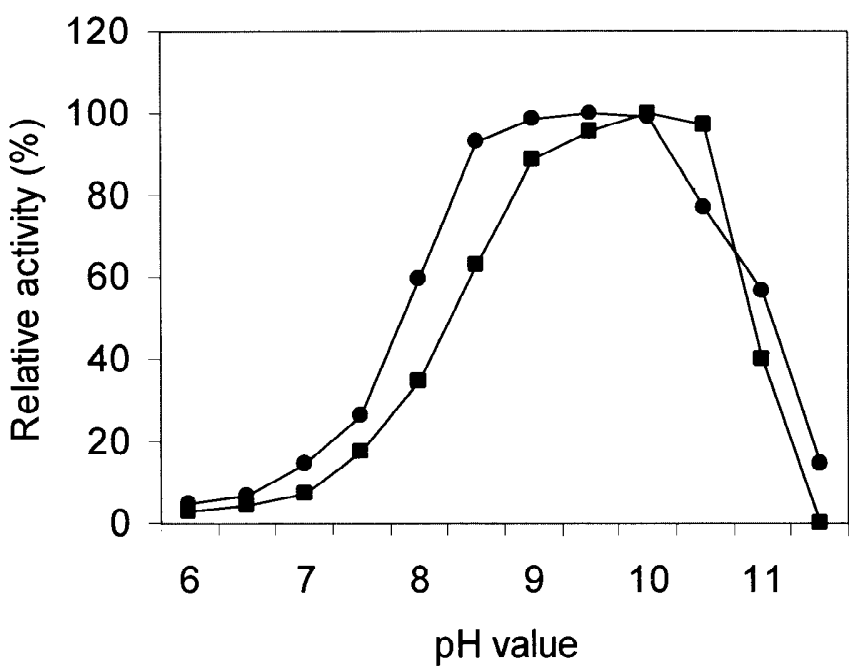

Fig. 5A, B. Effect of temperature (A) and $\mathrm{pH}(\mathbf{B})$ on the activity of the purified pectate lyase PelA (circles) and PelB (squares)

periplasmatic and extracellular E. coli protein fraction by ion-exchange chromatography. The purified pectate lyase protein fractions of PelA and PelB were determined by N-terminal sequencing of the first six amino acids. For PelA, an N-terminal amino acid sequence of SFNDGQ could be determined. In the case of PelB, three different fractions with pectinolytic activities were isolated (Fig. 4). The size of the biggest fragment of $75 \mathrm{kDa}$ is consistent with the theoretical molecular weight of $75 \mathrm{kDa}$ from PelB deduced from its amino acid sequence. The $\mathrm{N}$-terminal sequencing of these fragments showed AIYGGS in all cases, which is consistent with the theoretically deduced amino acid sequence of PelB. These N-terminal amino acid 

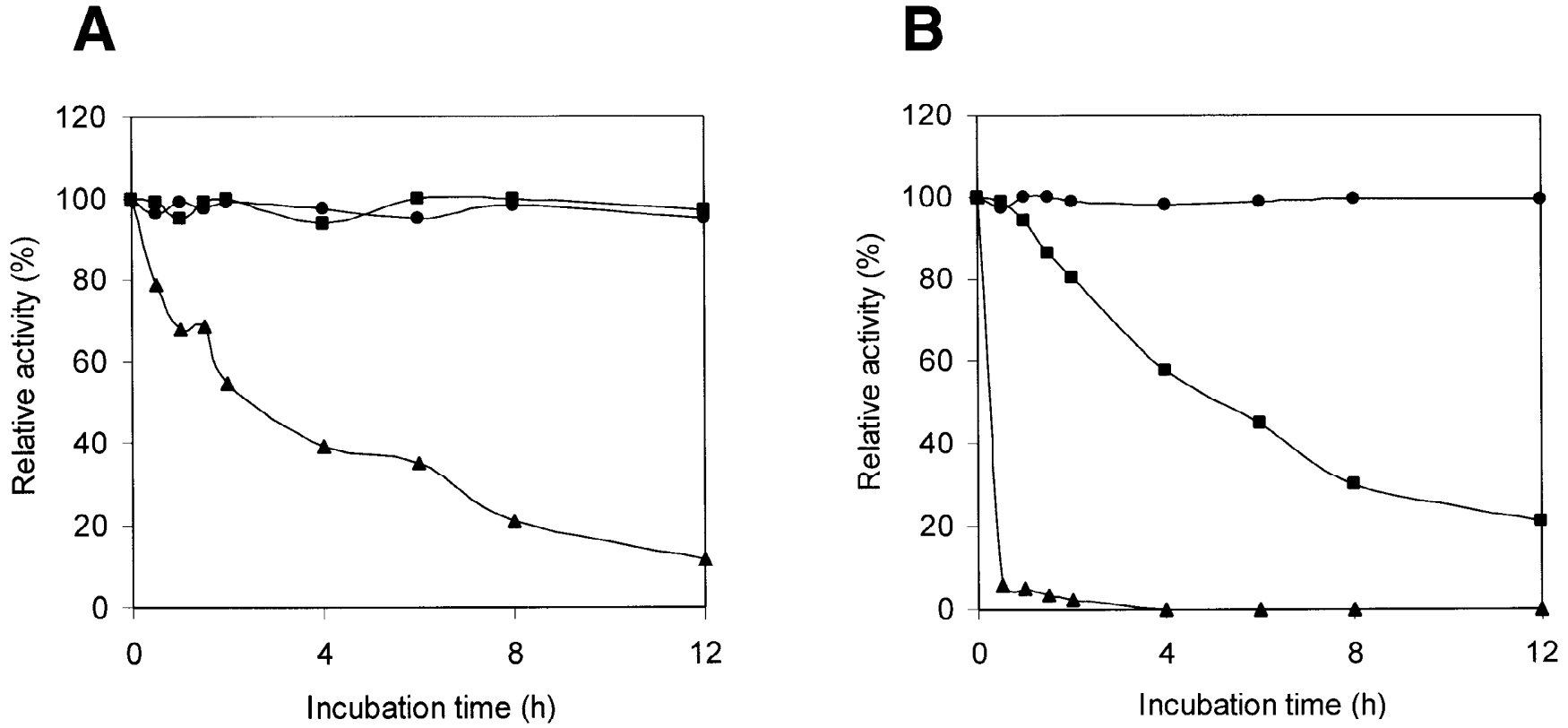

Fig. 6A, B. Thermostability of the pectate lyases PelA (A) and PelB (B) at $40^{\circ} \mathrm{C}($ triangles $), 30^{\circ} \mathrm{C}($ squares $)$, and $20^{\circ} \mathrm{C}($ circles $)$

A

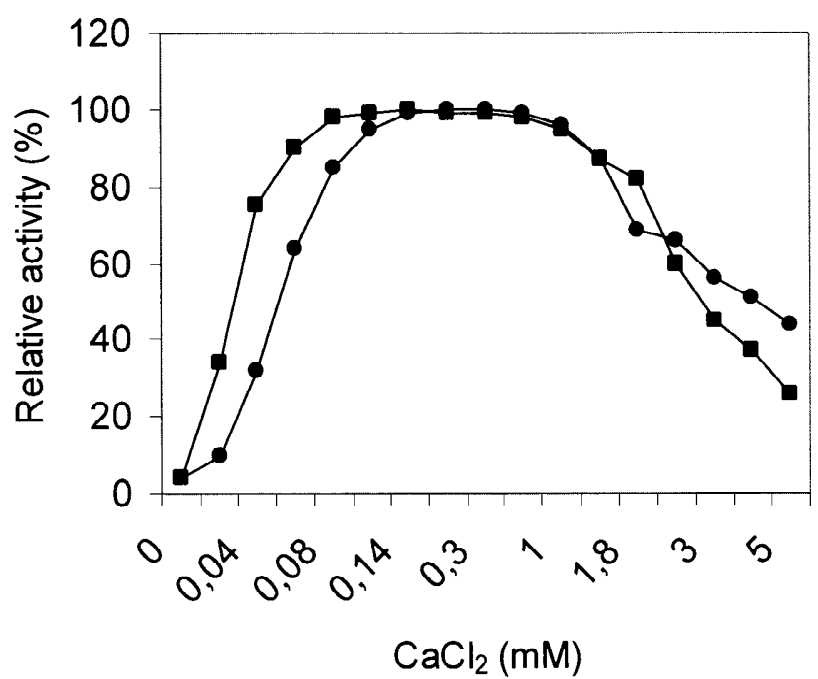

B

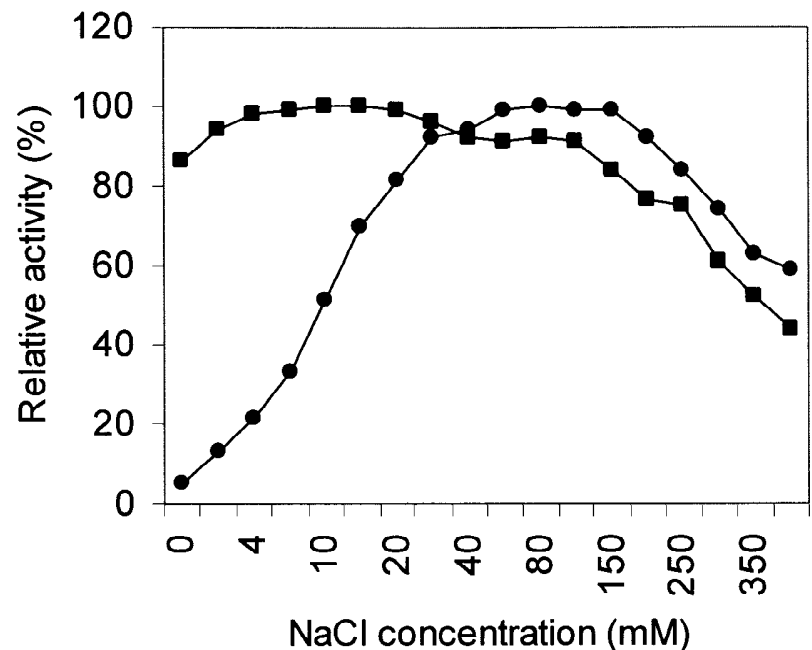

Fig. 7A, B. Dependence of the enzymatic activities of PelA (circles) and PelB (squares) on the presence of $(\mathbf{A}) \mathrm{Ca}^{2+}$ and $(\mathbf{B}) \mathrm{Na}^{+}$

sequences revealed that the signal peptides of both pectate lyases were correctly processed in E. coli.

For enzyme characterization, the purified protien fractions were used. The maximal enzymatic activities of both pectate lyases were found at $30^{\circ} \mathrm{C}$ (Fig. 5A). The remaining pectate lyase activity at $5^{\circ} \mathrm{C}$ was $25 \%$ for PelA and $35 \%$ for PelB. The optimal enzyme activity of PelA and PelB could be found at a $\mathrm{pH}$ range of 9-10 (Fig. 5B), which is a typical
pH of pectate lyases (Whitaker 1991). Both enzymes revealed a higher enzymatic activity with pectate than with pectin (data not shown). The $K_{\mathrm{m}}$ values of both lyases for pectate and citrus pectin were 1 and $5 \mathrm{~g} / \mathrm{l}$, respectively. PelA showed a higher stability at $30^{\circ} \mathrm{C}$ than PelB (Fig. 6). Although PelA did not show a decrease in enzymatic activity at $30^{\circ} \mathrm{C}$ during a12-h period (Fig. $6 \mathrm{~A}$ ), the half-life of PelB at $30^{\circ} \mathrm{C}$ was approximately $4 \mathrm{~h}$ (Fig. 6B). 
A typical feature of pectate lyases is the dependence of their enzymatic activity on the presence of $\mathrm{Ca}^{2+}$ (Whitaker 1991). PelA and PelB required $0.14-1 \mathrm{M} \mathrm{Ca}^{2+}$ for optimal activity on pectic substrates (Fig. 7 A), whereas the addition of $1 \mathrm{mM}$ ethylenediaminetetraacetic acid (EDTA) resulted in complete inhibition of the enzymes (data not shown). In contrast to PelB, the pectate lyase activity of PelA was also dependent on $\mathrm{Na}^{+}$(Fig. 7B); no enzyme activity of PelA could be measured if $\mathrm{NaCl}$ was not added to the medium. The presence or absence of $\mathrm{KCl}$ did not influence the enzyme activities of PelA and PelB.

\section{Discussion}

Little is known about pectin-degrading marine microorganisms. To date, pectinolytic marine microorganism have not been described in the literature. The strain ANT/505 investigated in this study is thus the first pectinolytic marine bacterium isolated from a permanently cold environment such as the Antarctic Ocean. According to the 16S rDNA sequencing, strain ANT/505 belongs to P. haloplanktis. Despite the $100 \%$ homology of the $16 \mathrm{~S}$ rRNA of this isolate to $P$. haloplanktis, the isolate ANT/505 differs in selected catabolic activities such as succinate, citrate, or glycerol utilization. Similar differences in catabolic activities could be found between two subspecies of $P$. haloplanktis (Gauthier et al. 1995).

The sequencing of the five pectinolytic clones of an ANT/505 gene library in E. coli and a sequence alignment with known protein sequences indicated that both pectinases belong to the group of pectate lyases (EC 4.2.2.2). This classification of the cloned pectinases of strain ANT/ 505 was supported by the enzyme characterization, which showed the two typical features of pectate lyases, dependence of enzymatic activities on an alkaline $\mathrm{pH}$ and the presence of $\mathrm{Ca}^{2+}$ (Whitaker 1991). The activity of the pectate lyase PelA of strain ANT/505 was dependent on sodium; other monovalent cations such as $\mathrm{K}^{+}$could not replace $\mathrm{Na}^{+}$. A similar dependence on sodium has been found with the pectate lyase PelE from E. chrysanthemi (Tardy et al. 1997). Furthermore, the determination of the formation of unsaturated bonds indicated that the enzymatic reaction of PelA and PelB of strain ANT/505 is based on the cleavage of the glycosidic bonds by a $\beta$-elimination (data not shown), which is the typical reaction of lyases (Collmer et al. 1988).

Several pectate lyases from mesophilic bacteria, above all from members of the genus Erwinia but also from the gram-positive genus Bacillus, have been cloned and characterized (Pissavin et al. 1996; Tardy et al. 1997; Shevchik et al. 1997; Bauer and Collmer 1997; Soriano et al. 2000). Recently, a thermostable pectate lyase from a newly isolated thermophilic bacterium, Thermoanaerobacter italicus, has been isolated and characterized (Kozianowski et al. 1997). Laurent et al. (2000) identified three cold-adapted pectate lyases from Chryseomonas luteola MFCL0. These enzymes macerated celeriac stored at low temperature.
However, to our knowledge no pectate lyase from a coldadapted microorganism has been cloned so far.

There is a significant homology of PelA and PelB of strain ANT/505 to the pectate lyases PelA, PelB, PelC, PelD, and PelE of E. chrysanthemi (Condemine and Robert-Baudouy 1991) and to PelA of A. nidulans (Ho et al. 1995). According to the classification of known pectate lyases (Shevchik et al. 1997), PelA and PelB could be affiliated to class I of this type of pectinases.

The overproduction of PelA or PelB in E. coli BL21 (DE3) with the exceptionally strong T7 expression system surprisingly did not result in a strong synthesis of these enzymes. Tierny et al. (1999) observed that recombinant vectors harboring a functional gene for a pectate lyase were rapidly lost in E. coli during the absence of selective pressure. They suggested that this plasmid instability was caused by to a toxic effect of the pel gene product when overproduced and was closely related to both a decrease of the growth rate and the impossibility of transforming different strains of $E$. coli with the recombinant plasmids harboring a functional pel gene. When the expression level of the pel gene was reduced, the stability was greatly improved. Such a toxic effect of pectate lyases could be at least one explanation for the low level of PelA and PelB from strain ANT/505 after the overexpression in E. coli.

Furthermore, the highest pectate lyase activity of PelB during the overexpression in $E$. coli could be observed when the optical density measured at $600 \mathrm{~nm}$ at the time of induction was not higher than 0.5 and optimal aeration of the culture was ensured. A higher cell density during induction with IPTG gave very low PelB activity in E. coli BL21 shake-flask cultures. It has been shown that the expression and activity of PelC, a pectate lyase from E. carotovora, was dependent on DsbA in E. coli (Humphreys et al. 1995). This periplasmic protein of $E$. coli is involved in the formation of disulfide bonds of secreted enzymes. Also, in the major E. chrysanthemi pectate lyases it has been shown that the cysteine residues are involved in disulfide bond formation (Yoder et al. 1993). In the case of PelB from strain ANT/505, two cysteines could be found. Thus, oxidative conditions could be required for the formation of disulfide bonds of the pectate lyase PelB and could thus determine the activity of this enzyme during the overexpression in $E$. coli BL21.

The thermoflexibility of cold-adapted enzymes is supposed to be prerequisite for the high catalytic activity of these proteins at low temperature (Gerday et al. 2000). However, this adaptation of psychrophilic proteins to lowtemperature conditions also determines an instability of these proteins at higher temperatures. Feller et al. (1998) observed that the cold-adapted amylase of $P$. haloplanktis cannot be functionally expressed in $E$. coli at $37^{\circ} \mathrm{C}$. Significant amylase activity could be only found at temperatures below $25^{\circ} \mathrm{C}$. During overexpression of the pectate lyases PelA and PelB of strain ANT/505 in E. coli, the highest enzyme activity could be determined in both cases at $30^{\circ} \mathrm{C}$ (data not shown). At $37^{\circ} \mathrm{C}$, a significantly lower activity for both pectate lyases could be observed. As PelB showed a half-life of approximately $5 \mathrm{~h}$ at $30^{\circ} \mathrm{C}$, it can be concluded 
that a lower temperature (e.g., $25^{\circ} \mathrm{C}$ ) would give a higher pectate lyase activity. However, because the T7 expression system works optimally in a temperature range from $30^{\circ}$ to $37^{\circ} \mathrm{C}$, a compromise between the thermostability of such cold-adapted enzymes and the optimal temperature for the expression system must be found.

The native polyacrylamide gel of the extracellular protein fraction indicated that the isolate ANT/505 has, ultimately, three extracellular pectinases. However, the overproduction of PelB in E. coli showed the same pectinase pattern in the supernatant, indicating that the three different extracellular pectinolytic activities in the wildtype strain ANT/505 are the result of degradation or processing of PelB. This assumption is supported by the $\mathrm{N}$ terminal sequencing, whereby it could be demonstrated that the PelB fragments purified from the E. coli supernatant have the same correct $\mathrm{N}$-terminal sequence.

Both enzymes, PelA and PelB, reveal an unusually long C-terminal part, which does not show any homology to other known pectate lyases. The C-terminus of PelA revealed a weak homology to the fimbrial adhesion protein of E. coli (Schmoll et al. 1989) and to the flagellin of Salmonella typhimurium (Homma et al. 1990). It is possible that this C-terminal domain plays a role in the localization of PelA in the cell wall compartment of P. haloplanktis ANT/ 505 and E. coli. The C-terminal part of PelB showed homologies to both xylanases of Streptomyces thermoviolaceus (Tsujibo et al.1997) and to Streptomyces coelicolor (Redenbach et al. 1996). Because the smaller processed PelB fragments missing the $\mathrm{C}$-terminus showed a pectinolytic activity similar to that of the larger wild-type fragment, this part of the enzyme is obviously not involved in the PelB pectate lyase activity. The processing of PelB remains obscure. For the pectate lyase PelI of E. chrysanthemi, processing at the N-terminus by extracellular host proteases has been described (Shevchik et al. 1998). It is interesting to note that the proteolytic processing of PelI also did not alter the pectate lyase activity. Thus, similar to the processed C-terminal part of PelB from strain ANT/505, the $97 \mathrm{~N}$-terminal amino acids of PelI also are not essential for enzymatic capacity.

The marine Antarctic bacterium P. haloplanktis ANT/ 505 was isolated from more than 500 strains from the Antarctic and Arctic Oceans as the only bacterium that produced significant pectinolytic activities under the conditions used in this study. This finding reflects the negligible role of pectin as a carbon source in these permanently cold marine environments. The two pectate lyases described in this study represent the first pectinases found in marine microorganisms.

Acknowledgments We gratefully acknowledge Heiko Laternicht for excellent technical assistance in the purification of the pectate lyases. We thank Holger Hippe for the N-terminal sequencing of the purified pectate lyases and the DSMZ for the $16 \mathrm{~S}$ rDNA sequencing. This work was financially supported by the Bundesministerium für Bildung und Forschung (BMBF).

\section{References}

Ahrens R (1968) Taxonomische Untersuchungen an sternbildenden Agrobacterium Arten aus der westlichen Ostsee. Kiel Meeresforsch 24:147-173

Bauer DW, Collmer A (1997) Molecular cloning, characterization, and mutagenesis of a pel gene from Pseudomonas syringae pv. lachyrmans encoding a member of the Erwinia chrysanthemi pelADE family of pectate lyases. Mol Plant-Microbe Interact 10(3):369-379

Bernfeld P (1955) Amilases a and b. In: Colowick SP, Kaplan NO (eds) Methods in enzymology. Academic Press, New York, pp 149-155

Burkholder PR (1963) Some nutritional relationships among microbes of the sea sediments and water. In: Oppenheimer H (ed) Symposium on marine microbiology. Thomas, Springfield, pp 133-155

Collmer A, Ried JL, Mount MS (1988) Assay methods for pectic enzymes. In: Wood WA, Kellog ST (eds) Methods in enzymology, vol 161. Academic Press, San Diego, pp 329-399

Condemine G, Robert-Baudouy J (1991) Analysis of an Erwinia chrysanthemi gene cluster involved in pectin degradation. Mol Microbiol 5:2191-2202

Cummings SP, Black GW (1999) Polymer hydrolysis in a cold climate. Extremophiles 3:81-87

Feller G, Le Bussy O, Gerday C (1998) Expression of psychrophilic genes in mesophilic hosts: assessment of the folding state of a recombinant alpha-amylase. Appl Environ Microbiol 64:1163-1165

Gauthier G, Gauthier M, Christen R (1995) Phylogenetic analysis of the genera Alteromonas, Shewanella, and Moritella using genes coding for small-subunit rRNA sequences and division of the genus Alteromonas into two genera, Alteromonas (emended) and Pseudoalteromonas gen. nov., and proposal of twelve new species combinations. Int J Syst Bacteriol 45:755-761

Gerday C, Aittaleb M, Bentahir M, Chessa JP, Claverie P, Collins T, D'Amico S, Dumont J, Garsoux G, Georlette D, Hoyoux A, Lonhienne T, Meuwis MA, Feller G (2000) Cold-adapted enzymes: from fundamentals to biotechnology. Trends Biotechnol 18:103107

Hanahan D (1983) Techniques of transformation in Escherichia coli. In: Glover DM (ed) DNA cloning, vol 1. IRL Press, Oxford, pp 109135

Helmke E, Weyland H (1984) Rhodococcus marinonascens sp.nov., an actinomycete from the sea. Int J Syst Bacteriol 34:127-138

Ho MC, Whitehead MP, Cleveland TE, Dean RA (1995) Sequence analysis of the Aspergillus nidulans pectate lyase pelA gene and evidence for binding of promoter regions to CREA, a regulator of carbon catabolite repression. Curr Genet 27:142-149

Homma M, DeRosier DJ, Macnab RM (1990) Flagellar hook and hook-associated proteins of Salmonella typhimurium and their relationship to other axial components of the flagellum. J Mol Biol 213:819-832

Humphreys DP, Weir N, Mountain A, Lund PA (1995) Human protein disulfide isomerase functionally complements a $d s b A$ mutation and enhances the yield of pectate lyase C in Escherichia coli. J Biol Chem 270:28210-28215

Keen NT, Tamaki S (1986) Structure of two pectate lyase genes from Erwinia chrysanthemi EC16 and their high-level expression in Escherichia coli. J Bacteriol 168:595-606

Kozianowski G, Canganella F, Rainey FA, Hippe H, Antranikian G (1997) Purification and characterization of thermostable pectate lyases from a newly isolated thermophilic bacterium, Thermoanaerobacter italicus $\mathrm{sp}$. nov. Extremophiles 1:171-182

Laurent P, Buchon L, Guespin-Michel JF, Orange N (2000) Production of pectate lyases and cellulases by Chryseomonas luteola strain MFCL0 depends on the growth temperature and the nature of the culture medium: evidence for two critical temperatures. Appl Environ Microbiol 66:1538-1543

Pissavin C, Robert-Baudouy J, Hugouvieux-Cotte-Pattat N (1996) Regulation of pelZ, a gene of the pelB-pelC cluster encoding a new pectate lyase of Erwinia chrysanthemi 3937. J Bacteriol 178:71877196

Redenbach M, Kieser HM, Denapaite D, Eichner A, Cullum J, Kinashi H, Hopwood DA (1996) A set of ordered cosmids and a detailed 
genetic and physical map for the $8 \mathrm{Mb}$ Streptomyces coelicolor A3(2) chromosome. Mol Microbiol 21:77-96

Sambrook J, Fritsch EF, Maniatis T (1989) Molecular cloning: a laboratory manual, 2nd edn. Cold Spring Harbor Laboratory Press, Cold Spring Harbor, NY

Schlemmer AF, Ware CF, Keen NT (1987) Purification and characterization of a pectin lyase produced by Pseudomonas fluorescens W51. J Bacteriol 169:4493-4498

Schmoll T, Hoschutzky H, Morschhauser J, Lottspeich F, Jann K, Hacker J (1989) Analysis of genes coding for the sialic acid-binding adhesin and two other minor fimbrial subunits of the S-fimbrial adhesin determinant of Escherichia coli. Mol Microbiol 3:1735-1744

Shevchik VE, Robert-Baudouy J, Hugouvieux-Cotte-Pattat N (1997) Pectate lyase PelI of Erwinia chrysanthemi 3937 belongs to a new family. J Bacteriol 179:7321-7330

Shevchik VE, Boccara M, Vedel R, Hugouvieux-Cotte-Pattat N (1998) Processing of the pectate lyase PelI by extracellular proteases of Erwinia chrysanthemi 3937. Mol Microbiol 29:1459-1469

Soriano M, Blanco A, Diaz P, Pastor FI (2000) An unusual pectate lyase from a Bacillus sp. with high activity on pectin: cloning and characterization. Microbiology 146:89-95

Tamaki SJ, Gold S, Robeson M, Manulis S, Keen NT (1988) Structure and organization of the pel genes from Erwinia chrysanthemi EC16. J Bacteriol 170:3468-3478
Tardy F, Nasser W, Robert-Baudouy J, Hugouvieux-Cotte-Pattat N (1997) Comparative analysis of the five major Erwinia chrysanthemi pectate lyases: enzyme characteristics and potential inhibitors. J Bacteriol 179:2503-2511

Tierny Y, Hounsa CG, Hornez JP (1999) Effects of a recombinant gene product and growth conditions on plasmid stability in pectinolytic Escherichia coli cells. Microbios 97:39-53

Tsujibo H, Ohtsuki T, Iio T, Yamazaki I, Miyamoto K, Sugiyama M, Inamori Y (1997) Cloning and sequence analysis of genes encoding xylanases and acetyl xylan esterase from Streptomyces thermoviolaceus OPC-520. Appl Environ Microbiol 63:661-664

Weyland H, Rüger HJ, Schwarz H (1970) Zur Isolierung und Identifizierung mariner Bakterien. Veröff Inst Meeresforsch Bremerh 12:269-296

Whitaker JR (1991) Microbial pectolytic enzymes. In: Fogarty WM, Kelly CT (eds) Microbial enzymes and biotechnology. Elsevier, London, pp 133-176

Völker U, Mach H, Schmid R, Hecker M (1992) Stress proteins and cross-protection by heat shock and salt stress in Bacillus subtilis. J Gen Microbiol 138:2125-2135

Yoder MD, Keen NT, Jurnak F (1993) New domain motif: the structure of pectate lyase $\mathrm{C}$, a secreted plant virulence factor. Science 260:1503-1507 